\title{
MICROBIAL QUALITY OF CHICKEN BROILER CARCASSES
}

\author{
*Nader, Y. Mostafa ;"Ghada, A.K. Kirrella; ${ }^{* *}$ Ahmed, M. ELgaml \\ and ${ }^{* *}$ Heba, M. M. Kamouh
}

"Food Control Dept, Faculty of Veterinary Medicine, Kafrelsheikh University, Egypt ${ }^{* *}$ Animal Health Research Institute, Mansoura branch, Egypt

\section{ABESTRACT}

A total of 130 random samples of chicken carcasses including; 60 of frozen chicken carcasses, and 70 of freshly slaughtered chicken carcasses were collected from different private poultry shops, supermarkets and retailing shops in EL Gharbia Governate.

It was found that TAC ranged from $5 \times 10^{3}$ to $2.80 \times 10^{6}$ and $1 \times 10^{5}$ to $1.79 \times 10^{8}$ with a mean value $3.2 \times 10^{5} \pm 5.5 \times 10^{4}$ and $3.41 \times 10^{7} \pm$ $5.42 \times 10^{6} \mathrm{cfu} / \mathrm{g}$ in frozen and freshly slaughtered chicken carcasses, respectively.Also, it was recorded that the mean values of TCC in frozen and freshly slaughtered chicken carcasses $1.5 \times 10^{2} \pm 1.16 \times 10$ and $4.07 \times 10^{4} \pm 5.09 \times 10^{3} \mathrm{cfu} / \mathrm{g}$ respectively. Furthermore, pathogenic E. coli was isolated from frozen and fresh chicken carcasses samples with an incidence of $10 \%$ and $5 \%$, respectively. The identified strains of Enteropathogenic E. coli from examined frozen and fresh chicken carcasses were O128:H2, O111:H4, O26:H11, O142, O55:H7 and O119:H4. In addition, total Staphylococcal count was done and it ranged in frozen and freshly slaughtered chicken carcasses from $5 \times 10$ to $2.04 \times 10^{5}$ and $2.00 \times 10^{3}$ to $2.08 \times 10^{6}$ with a mean value $1.75 \times 10^{4} \pm$ $5.37 \times 10^{3}$ and $2.26 \times 10^{5} \pm 4.57 \times 10^{4} \mathrm{cfu} / \mathrm{g}$. The rate of isolation of Staph.aureus in frozen chicken carcasses and freshly slaughtered chicken carcasses was 15 (9 isolates) and 20\% (14 isolates), 
respectively Finally, it was found that total mould and yeast count in frozen and freshly slaughtered chicken carcasses ranged from $5 \times 10$ to $1.75 \times 10^{3}$ and $3.00 \times 10^{2}$ to $1.5 \times 10^{6}$ with a mean value $3.43 \times 10^{2} \pm$ $5.78 \times 10$ and $1.83 \times 10^{5} \pm 3.98 \times 10^{4} \mathrm{cfu} / \mathrm{g}$ respectively. also the rate of isolation of salmonella 0,10\% from frozen and fresh chicken carcasses samples, respectively. Accordingly from the chicken carcasses possessed significant number of bacteria with significant risk of carcasses spoilage and public healthhazards.

Key words: Microbial quality,broilers carcasses,Aerobic bacterial counts, coliform counts, Staphylococcal counts, Staph. aureus ,Salmonella,E.coli.

\section{INTRODUCTION}

Poultry meat is more popular as it is easy digestible and accepted by majority of people so its consumption had dramatically increased in recent decades all over the world rather than any meat type (Sams, 2001). However, poultry and poultry meat products have been implicated as major sources of Salmonella infection in human (Amavisit et al., 2001).

Microbial conditions of poultry meat depend mainly on the initial bacterial load and the microbial species carried on the skin, in the gastrointestinal tract or in the muscle, which are influenced by farm practices and, most of all, by slaughtering procedures (Mexis et al., 2012).

Microorganisms enter the food by raw ingredients, water, environmental cross contamination, inadequate sanitation and poor handling practices during cooking and serving. Certain microbial contamination of food is an indicator of poor sanitary practice in the 
preparation and storage of foods. Mishandling in foodservice establishments can contribute significant outbreak of food-borne diseases (Frazier \&Westhoff, 2001).

Coliform may be fecal or non fecal in origin. The high count of coliforms on chicken carcasses taken after evisceration might be due to the contamination of the carcasses from the intestinal contents and cross contamination from the eviscerating table. Coliform count is used as an index of the overall hygienic condition prevailing during the processing of food (Koenacki and Johnson 2001).

The standard counting of mesofile bacteria is used as an indication of the hygienic quality of the food. The index of totalcoliforms evaluates the hygienic conditions and the index of fecal coliforms is used as an indication of fecal contamination (Cardoso et al., 2000).

Yeast contamination of food is considering a useful indicator to evaluate the food quality. The degree of deterioration is an essential component for microbiological assurance programs (Marta et al., 2001).

Staphylococcus aureus may contaminate poultry meat and poultry products during processing and contamination of poultry meat depends, in particular, on the production techniques and methods such as the rearing conditions of the animals, transport conditions of live animals, scalding and plucking procedures and, to a large degree, on the evisceration techniques (Ellerbroek, 2004).

Food borne salmonellosis due to Salmonella typhimurium and Salmonella enteritidis are transmitted to human by the animal reservoirs of Salmonella infection and through food such as contaminated milk, meat, poultry meat, eggs and their products with infective dose (Humphrey, 2006). 
E. coli O157:H7 causes severe illnesses and a low infective dose is required for infection, it is considered one of the most serious food borne pathogens (Teunis et al.,2004).

\section{The aim of the present work lies in:}

1. Determination of the required sanitary measures to minimize the possible hazards of consuming poultry meat.

2. Investigation of the prevalence of food poisoning microorganisms in chicken broiler meat as well as discuss the public health importance of the isolated microorganisms.

3. Securing the following information about bacteriological evaluation of frozen and freshly slaughtered chicken carcasses for aerobic bacterial count, coliform count, staphylococcus count, yeast \&mold count and isolation and identification of(Staph aureus, Salmonella and E.coli)

\section{MATERIALS AND METHODS}

\section{Collection of samples:}

A total of 130 poultry carcass were randomly collected from different shops and supermarkets at EL Gharbia Governorate (Egypt) aseptically in separate sterile plastic bag, each sample was subjected to bacteriological examination (total bacterial count, coliforms count, total staphylococcus count, total yeast and mould count, Staphylococcus aureus isolation and Salmonella isolation, Ecoli isolation).

Frozen chicken meat kept in deep-freezers (temperature $-18{ }^{\circ} \mathrm{C}$ ), and fresh chicken meat in cooling showcases (temperature $+4{ }^{\circ} \mathrm{C}$ ). TheSamples were transported to the laboratory immediately after collection in an ice box and tested upon arrival or stored at $2^{\circ} \mathrm{C}$ for no longer than 4hours. 
Microbial Quality Of Chicken Broiler Carcasses.

2. Preparation of samples (APHA, 1992):

Ten grams of each sample were aseptically transferred into a sterile flask containing $90 \mathrm{ml}$ of $0.1 \%$ sterile peptone water homogenized for 2 minutes to get a dilution of $10^{-1}$. From this dilution, tenth fold serial dilutions up to $10^{-10}$ were done.

\section{Microbiological examination:}

3.1.Determination of total aerobic bacterial count (APHA 2001)

3.2. Determination of Total coliforms count (ICMSF, 1978)

The suspected colonies were purified and identified as follow:

Morphological examination:

I. Staining (Cruickshank, Duguid et al. 1975)

II. Motility test (ICMSF 1996)

Biochemical identification (FDA 1998):

I. IMVIC pattern

II. Urea hydrolysis test

III. Sugar fermentation test

IV. Triple sugar iron test

\section{Serological identification of isolated culture:}

The Escherichia coli strains presumed to be Ecoli O157 were serologically confirmed using IGM antibodies to $\mathrm{O} 157$ according to instruction of the manufacture. 
3.3. Determination of Staphylococcus (ISO 6888, (1999):

The suspected colonies were purified and identified as follow:

\section{Morphological examination:}

I. Staining (Cruickshank, Duguid et al. 1975)

II. Motility test (ICMSF 1996)

\section{Biochemical identification:}
A. Catalase activity testb (MacFaddin,1976)
B. Detection of haemolysis (Baily and Scott, 1978).
C. Mannitol test (Baily and Scott, 1978).
D. Coagulase test $(A P H A, 2001)$

\subsection{Determination of total mould count (ICMSF) (1978)}

\subsection{Determinationof Salmonella (ISO 6579, (2002)}

The suspected colonies were purified and identified as follow:
a) $\mathrm{H} 2 \mathrm{~S}$ production using Triple sugar iron Agar (TSI).
b) Lysine decarboxylase in Lysine Iron Agar.
c) Urea hydrolysis in urea agar.
d) Indole test
e) MR test
f) VP test
g) Simmons Citrate 
Microbial Quality Of Chicken Broiler Carcasses.

\section{RESULTS}

Table (1): Microbial profile of the examined broiler carcass samples.

\begin{tabular}{|c|c|c|c|}
\hline Group & No. & \% of pos samples & Mean \pm S.E \\
\hline \multicolumn{4}{|c|}{ Total aerobic count } \\
\hline Fresh & 70 & $100 \%$ & $3.41 \times 10^{7} \pm 5.42 \times 10^{6}$ \\
\hline Frozen & 60 & $100 \%$ & $3.2 \times 10^{5} \pm 5.5 \times 10^{4}$ \\
\hline \multicolumn{4}{|c|}{ Total coliform count } \\
\hline Fresh & 70 & $100 \%$ & $4.07 \times 10^{4} \pm 5.09 \times 10^{3}$ \\
\hline Frozen & 60 & $60 \%$ & $1.5 \times 10^{2} \pm 1.16 \times 10$ \\
\hline \multicolumn{4}{|c|}{ Total staphylococcus count } \\
\hline Fresh & 70 & $100 \%$ & $2.26 \times 10^{5} \pm 4.57 \times 10^{4}$ \\
\hline Frozen & 60 & $86.67 \%$ & $1.75 \times 10^{4} \pm 5.37 \times 10^{3}$ \\
\hline \multicolumn{4}{|c|}{ Total yeast \& mold count } \\
\hline Fresh & 70 & $100 \%$ & $1.83 \times 105 \pm 3.98 \times 104$ \\
\hline Frozen & 60 & $86.67 \%$ & $3.43 \times 10^{2} \pm 5.78 \times 10$ \\
\hline
\end{tabular}

Table (2): Incidence of pathogenic microorganisms in the examined broiler carcass samples.

\begin{tabular}{|c|c|c|c|}
\hline Bacterial Group & No. & $\mathrm{N}$ of pos samples & \% of pos samples \\
\hline \multicolumn{4}{|l|}{ Staphylococcus aurus } \\
\hline Fresh & 70 & 21 & $30 \%$ \\
\hline Frozen & 60 & 9 & $15 \%$ \\
\hline \multicolumn{4}{|l|}{ salmonella } \\
\hline Fresh & 70 & 7 & $10 \%$ \\
\hline Frozen & 60 & 0 & $0 \%$ \\
\hline \multicolumn{4}{|l|}{ Ecoli } \\
\hline Fresh & 70 & 7 & $10 \%$ \\
\hline Frozen & 60 & 3 & $5 \%$ \\
\hline
\end{tabular}

Table (3): Serotyping of Salmonellae isolated from the examined poultry carcasses samples.

\begin{tabular}{|c|c|c|c|c|c|c|}
\hline \multirow{2}{*}{ No } & \multirow{2}{*}{ Identified strains } & \multirow[t]{2}{*}{ Group } & \multicolumn{2}{|c|}{ Positive samples } & \multicolumn{2}{|c|}{ Antigenic structure } \\
\hline & & & No. & $\%$ & $\mathbf{O}$ & $\mathbf{H}$ \\
\hline 1 & Salmonella Enteritidis & D1 & 2 & 1.4 & $1,9,12$ & $\mathrm{~g}, \mathrm{~m}$. , \\
\hline 2 & Salmonella Typhimurium & $\mathrm{B}$ & 3 & 2.1 & $1,4,5,12$ & $\mathrm{i}: 1,2$ \\
\hline 3 & Salmonella Kentucky & $\mathrm{C} 3$ & 1 & 0.7 & 8,20 & $\mathrm{i}: \mathrm{z6}$ \\
\hline 4 & Salmonella Muenster & E1 & 1 & 0.7 & $3,10,15,34$ & e,h:1,5 \\
\hline
\end{tabular}

Table (4): Serotyping of E.coliisolated from the examined poultry carcasses samples.

\begin{tabular}{|c|c|c|c|}
\hline No & Identified strains & Serodiagnosis & Strain characterization \\
\hline 1 & E.coli & $\mathrm{O} 128: \mathrm{H} 2$ & ETEC \\
\hline 2 & E.coli & O111:H4 & EHEC \\
\hline 3 & E.coli & O26:H11 & EHEC \\
\hline 4 & E.coli & $\mathrm{O} 142$ & EPEC \\
\hline 5 & E.coli & O55:H7 & EPEC \\
\hline 6 & E.coli & O119:H4 & EPEC \\
\hline
\end{tabular}

Kafrelsheikh Vet. Med. J. Vol. 14 No. 1 (2016) 


\section{DISCUSSION}

\section{Total aerobic bacterial count:}

The total aerobic bacterial count indicates the hygienic practices applied during processing and keeping quality of meat products and can be routinely used as indicators of improper hygiene during processing and incorrect storage conditions, which can lead to proliferation of pathogens, such as salmonella and toxin production (Zweifel et al., 2005).

The results obtained in table (1) showed that $100 \%$ of examined fresh and frozen poultry carcass samples were ranged from $5 \times 10^{4}$ to $1.79 \times 10^{8}$ and $5 \times 10^{3}$ to $2.80 \times 10^{6}$ with a mean value of $3.42 \times 10^{7} \pm$ $5.42 \times 10^{6}$ and $3.2 \times 10^{5} \pm 5.5 \times 10^{4}$, respectively.

Nearly similar results were reported by Ola (2015). While lower results were reported by Nassar (2013), Abukora (2012), Khlifa et al., (2005) and Samar (2011) while higher results were reported by Ibrahim (2013) in fresh poultry carcass samples, while in frozen poultry carcass samples nearly similar results were reported by Ola (2015).

\section{Total coliform count:}

High coliforms counts indicate poor Hygienic quality of meat. The contamination with coliforms may occur during slaughtering, cutting or dressing of carcasses, soiled hands, shopping blocks or knives used for handling and cutting or contaminated water (Yadav et al., 2006).

The results obtained in table (1) showed that $100 \%$ and $60 \%$ of fresh and frozen poultry carcass samples were contaminated with coliform and the total Coliform counts were ranged from $3 \times 10^{2}$ to $1.22 \times 10^{5}$ and $4 \times 10$ to $2.95 \times 10^{2}$ with mean values of $4.07 \times 10^{4} \pm$ 
$5.09 \times 10^{3}$ and $1.5 \times 10^{2} \pm 1.16 \times 10$, respectively. Nearly similar results were reported by Ola (2015) in both fresh and frozen poultry carcass samples but lower result reported by Ibrahim (2013) and Daoud et al.. (2012).

\section{Total staphylococcal count:}

The high count of Staphylococci in these products is indicative of a human handling contamination as these organisms are the commensals of human skin and mucosal surfaces and also related to unhygienic practices during different stages of processing and marketing (Mottin et al., 2010).

Results obtained in table (1) revealed that $100 \%$ and $86.67 \%$ of fresh and frozen poultry carcass samples were contaminated with Staphylococci with a count ranged from $2.00 \times 10^{3}$ to $2.08 \times 10^{6}$ and $5 \times 10$ to $2.04 \times 10^{5}$ with a mean value $2.26 \times 10^{5} \pm 4.57 \times 10^{4}$ and $1.75 \times 10^{4} \pm$ $5.37 \times 10^{3}$, respectively.

Nearly similar results were reported by Ola (2015) in both fresh and frozen poultry carcass samples while the lower results were reported by Ibrahim (2013) in fresh poultry carcass samples.

\section{Total mold and yeast count:}

Yeast contamination of food is considering a useful indicator to evaluate the food quality. The degree of deterioration is an essential component for microbiological assurance programs (Marta et al., 2001).

Results obtained in table(1) revealed that $100 \%$ and $86.67 \%$ of fresh and frozen poultry carcass samples were contaminated with yeast and mold with a count ranged from $3.00 \times 10^{2}$ to $1.5 \times 10^{6}$ and 5 to $1.75 \times 10^{3}$ with a mean value $1.83 \times 10^{5} \pm 3.98 \times 10^{4}$ and $3.43 \times 10^{2} \pm$ $5.78 \times 10$, respectively. 
Lower results were reported by Ola (2015), Ibrahim (2013), AbdElrahman (2013) and Captia et al, (2001), Higher result obtained by Nassar(2013) while nearly similar results were reported by Ola (2015) in frozen poultry carcass samples.

Incidence of $S$. aureus:

Staph auras according to colonial characters and $30 \%$ and $15 \%$ according to biochemical identification, lower results were obtained by Cohen et al,. (2007) and Capita et al,. (2001) While the higher results were obtained by Nassar (2013), Ibrahim (2013) and Abukora (2012).

\section{Isolation and identification of Salmonellae:}

Table (2) showed that 10 of examined fresh poultry carcass samples according to biochemical identification presumed to contain salmonella organisms.

Nearly similar results were obtained by Abukora (2012) and Kozacinski et al., (2006), Lower results were obtained by Mohamed et al., (2012) and Carvalho et al.,(2002). Higher results were obtained by Ejeta et al., (2004) and Nassar (2013), while salmonella could not detected in any samples in frozen poultry meat according to Moharum (2005), and higher results were obtained by Tessari et al. (2008).

The higher rate of incidence of Salmonella could be attributed to lack of proper cold chains, inadequate power supply, and low levels of hygiene in retail outlets Bhattacharya and Dash (2007). 
Isolation and identification of E.coli $\mathrm{O}$ 157: $\mathrm{H7}$ :

Table (2) showed that 10, 5\% of the examined fresh and frozen poultry carcass samples according to biochemical identification positive for Ecoli.

Higher results obtained by Nassar (2013), the lower results obtained by Abukora (2012), while in frozen poultry meat higher results obtained by Elnawawi (2012) and lower results obtained by Tolba (2000) and Biswas (2008).

The results recorded that $0 \%$ of examined fresh poultry meat, and frozen poultry meat samples for presence of E.coli O157:H7.nearly similar results obtained by Tolba (2000), but higher results obtained by Kihal and Barka (2010).

\section{CONCLUSION}

Informations given by the obtained results, allow to conclude that, the majority of chicken meat samples were highly contaminated and exceeded the permissible limits that recommended by the Egyptian authority and this reflect the unhygienic measures and unsuitable environmental condition during processing and handling, thus it is of a great importance to have an established program of Plant employee education and training in proper food handling technique and food protection principles that stress the dangers of poor personal hygiene and unsanitary practices as well as uneffecient storage and low quality of raw materials. 


\section{REFERENCE}

- Abd-Elrahman, H. A.; Soliman, S.A. and Rahal, E. G (2013): Prevalence of yeast in chicken meat and their products. Dept. of Food hygiene \& control, Faculty of Veterinary. Medicine, Suez Canal University,Ismailia,Egypt.SCVMJ, XVIII (2) 2013.

- Abukora, HossamShaban El-Sebaee(2012): PhD thesis Bacterial and Viral View of Poultry Meat Prepared in Private Poultry Shops .Faculty of veterinary medicine .Alexandria University.

- Amavisit, P., Browning, G. F., Lightfood, D.,Anderson, C. S. (2001): Rapid PCR detection of Salmonella in horse faecal samples. Vet. Microbiol.79:63-74.

- APHA, A. P. H. A. (2001): "Compendium of methods for the microbiological examination of foods, 4th edition. American Public Health Association (APHA). Washington, DC USA."

- Bailey, W.R., Scott, E.G. (1978): Diagnostic Microbiology. A textbook for the isolation and identification of pathogenic microorganisms. 5th Ed., Carroll B. Larson and Marjorie Gould Publisher, Saint Louis, C.V. Mosby Co., Missouri, USA.

- Baird, R. M. and Lee, W. H. (1995): Media used in the detection and enumeration of Staphylococcus aureus. International Journal Food Microbiology 26, 15-24.

- Bhattacharya, S.S. and Dash, U.A.( 2007): Sudden raise in occurrence of Salmonella paratyphiA infection in Rourkela, Orissa. Indian Journal of Medical Microbiology 25: 78-79. 
- Biswas, A.K., N. Kondaiah, K.N. Bheilegaonkar, A.S.R. Anjaneyulu, S.K. Mendiratta, C. Jana, H. Singh and R.R. Kumar, (2008): Microbial profiles of frozen trimmings and silver sides prepared at Indian buffalo meat packing plants. Meat Sci., 80: 418-422.

- Capita, R.; Alonso-Calleja, C.; Garcia-Fernandez, M. del C. and Moreno, B. (2001): Microbiological quality of retail poultry carcasses in Spain. Journal of Food Protection. 2001. 64: 12, 1961-1966.

- Cardoso, A. L. S. P.; Tessari, E. N. C.; Castro, A. G. M.; Kanashiro, A. M. I. (2000): Research of Salmonella spp., fecal coliforms, total coliforms and mesofilos in carcass of broiler and derived products. Arquivos do InstitutoBiologico (Sao Paulo).2000. 67:1,25-30. 17 ref.

- Carvalho, A. C. de F. B. de; Florioto, J. F.; Pereira, G. T.; Schocken-Iturrino, R. P. (2002): Microbiological evaluation of mechanically retrieved poultry meat.HigieneAlimentar. 2002. 16: 98, 91-100. 38 ref.

- Cohen, N.; Ennaji, H.; Bouchrif, B.; Hassar, M.; Karib, H. (2007): Comparative study of microbiological quality of raw poultry meat at various seasons and for different slaughtering processes in Casablanca (Morocco). Journal of Applied Poultry Research. 2007.16,502-508.

- Cruickshank K., R., Dugid, J.P., Marmion, B.P. and Swain, R. H. A. (1975): Method microbiology.The practice of medical microbiology. VII.12 ${ }^{\text {th }}$ Ed.,Churchill Livingstone Edinburgh,London and New York.

- Ejeta,G., Molla,B.,Alemayehu,D. and Muckle, A. (2004): Salmonella serotypes isolatedfrom minced meat beef, mutton and pork in Addis Ababa, Ethiopia. Revue de médecine vétérinaire 155, 547-551. 
- Ellerbroek, L. I. (2004): Research update on major pathogens associated with the processing of poultry and poultry products. Safety assurance during food processing: food safety assurance and veterinary public health, Volume 2. 2004. 81-98. Many refs.

- El-Shamy, Samar Yahia Mohammed (2007): PhD thesis Relationship Between Aerobic Bacteria, Salmonella and Campylobacter On Broiler Carcasses. Faculty of veterinary medicine. Alexandria University.

- KHALIFA. E. M. I. and ABD EL-SHAHEED. Y. T. U. (2005): Bacteriological Evaluation Of Chicken meat and some chicken meat product sold in Kafer El - Sheikh Governate. Animal Health Research Institute Kafr EL-Sheikh branch. $4^{\text {Th }}$ Int. ९Sci. Conf., MANSOURA. 5-6 April 2005.

- Fathi A. Elnawawi, Osama A. Attala and SamaaSaleh (2012): Enteropathogens of Public Health Importance in Imported Frozen Meat and Chicken. Department of Food Hygiene and Control, Faculty of Veterinary Medicine, Cairo University, Egypt. International Journal of Microbiological Research 3 (1): 59-63, 2012.

- Frazier, W.C and D.C. Westhoff. (2001): Food microbiology. TataMcGrow Hill.

- Ibrahim, Mohamed Ibrahim Ahmed (2013): $\mathrm{PhD}$ thesis Microbiological Comparison between Broiler Chickens Produced in Poultry Abattoir and Private Shops. Faculty of veterinary medicine .Alexandria University. 
- I. C. M. S. F.; International commission on microbiological specifications for foods (1978): Microorganisms in foods I. their significance and enumeration $2{ }^{\text {nd }}$ Ed Univ., of Toronto press, Toronto and Buffalo, Canada.

- I.C.M.S.F.; International commission on microbiological specifications for foods (1980): Factors Affecting life and Death of Microbial Ecology of food, 1:126.

- ISO (International organization for Standardization) 6888 (1999): Microbiology of food and animal feeding stuff-Horizontal method for the enumeration of coagulase-positive staphylococcus (staphylococcus aureus and other species)Part 1: technique using Baird-Parker agar medium. First edition (1999-02-15).

- ISO(International organization for Standardization) 6579 (2002): Microbiology of food and animal feeding stuffs. Horizontal method for the detection of Salmonella ISB Number 0580402827. Geneva, Switzerland: fourth edition 2002-07-15.

- Daoud, J. R. (2012): Microbial quality of frozen chicken meat at grocery stores in qena city", International Conference and Exhibition on Food Processing \& Technology, 2012.

- Kihal, M. and Barka, M.S. (2010): Prevalence of of,Escherichia Coli Enterohemorragic O : H in Frozen Bovine Meat in Algeria. J. Applied Sciences Res., 6(11): 1576-1580.

- Koenacki, J.L. and Johnson J.L. (2001): Enterobactericae, coliforms and Escherichia coli as quality and safety indicators. In : Downes, F.P. and Ito, K.(Eds) Compendium of methods for the microbiological examination of foods. 4th ed. American public health association. Washington DC. pp. 69- 82. 
- Kozacinski,L.;Hadziosmanovic,M.;Zdolec,N.(2006): Microbiological quality of poultry meat on the Croatian market. VeterinarskiArhiv. 2006. 76: 4, 305-313. 24 refs.

- Macfaddin, J.F. (1976): Biochemical tests for identification medical bacteria. Warery press Inc, Baltimore, Md. 21202 USA.

- Marta H.T., Silva N., Banhi A.A. and Iamanaka B.T. (2001): Comparison of culture media, simplate and petrifilm for enumeration of yeasts and molds in foods. Journal of Food Protection, 64: 15921596.

- Mexis SF, Chouliara E, Kontominas MG, (2012): Shelf-life extension of ground chicken meat using an oxygen absorber and a citrus extract. Food SciTechnol-LEB 49:21-7.

- Mohamed Mohamed-Noor SE, Shuaib YA, Suliman SE, Abdalla MA. (2012): Study of microbial contamination of broiler in modern abattoirs in Khartoum State. The Annals of the university dunarea de Jos of Galati; 2012.

- Moharum, A., (2005): Quality of locally produced and imported frozen beef. M.V. Sc. thesis, Meat Hygiene. Dep. Fac., Vet. Med. Cairo Univ.

- Mottin, V. D., Fisch, E. and Cardoso, M. R. d. I. (2010): Microbial contamination of luncheon meat sliced and packaged at supermarkets in Porto Alegre, Brazil. Acta scientiae veterinariae. Porto Alegre, RS. Vol. 39, 1-6.

- Nassar, Mohammed Mohamedain Mahmoud (2013): $\mathrm{PhD}$ thesis Comparison of Microbiological Profile Between Rural and Industrial Poultry. Faculty of veterinary medicine. Alexandria University. 
- Ola Said AwadHassan (2015): Ph.D thesis Microbiological Status Of Poultry Carcasses from Retailed Outlets In Alexandria Province. Faculty of veterinary medicine. Alexandria University.

- Sams, A.R.(2001): First processing: Slaughter through chilling. Pages 19-34 in Poultry Meat Processing. A. Sams, ed. CRC Press LLC, Boca Raton, FL.

- Tessari, E.N.C., Sicchioroli, A.L., Cardoso, P., Kanashiro, A.M.I., Stoppai, G.F.Z., Luis, R.and Castro, L.A.G.M. (2008): Ocorrência de Salmonella spp. emcarcaças de frangosindustrialmenteprocessadas, procedentes de exploraçõesindustriais do Estado de São Paulo, Brasil. Ciência Rural 38(9):2557-2560.

- Tolba, K., (2000): Sanitary status of marketed frozen chicken products exhibited in presentation freezers. Complete.

- Teunis, P., Takumi, K. and Shinagawa, K. (2004): Dose Response for Infection by Escherichia coli O157:H7 from Outbreak Data. Risk Analysis 24, 401-407.

- Yadav, M., Tale, S., Sharda, R., Sharma, V., Tiwari, S., Garg, U. (2006): Bacteriological quality of sheep meat in Mhow town of India. Inter. J. Food Sci.Technol., 41: 1234-1238.

- Zweifel, C., Baltzer, D., Stephan, R. ( 2005):Microbiological contamination of cattle and pig carcasses at five abattoirs determined by swab sampling in accordance with Eu Decision 2001/471/EC.J. Meat Sci., 69:559-566. 
الجوده الميكروبيه لذبائح دجاج التسمين

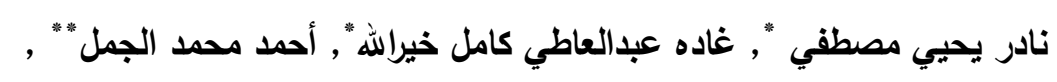

هبه مصطفى محمد قموح"*

" كلية الطب البيطري- جامعة كفر الثيخ - قسم الرقابة الصحبة على اللحوم

" معهز بحوث صحة الحيوان - فرع المنصورة

اجريت هذه الدراسـة علي بعض منتجـات اللحوم في محافظـه الغربيـة وذللك لتقييم الجودة البكتريولوجية لهذه المنتجات المتداوله في الاسواق وذللك تم تجميع 130 عينه عشوائيه ( 70 عينه دجاج طازج , 60 عينه دجاج مجمد) من بعض المحلات والسوبر ماركت المختلفة بمحافظه الغربية وقد تم

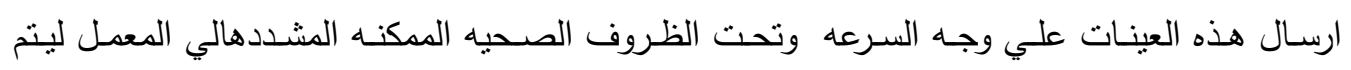

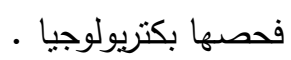

وقد دلت النتائج على أن منوسط العدد الكلي للميكروبات الهوائية في كلا من عينات الدجاج الطازج والمجمد كالتالى (3,41 × كما أظهرت النتائج أن متوسط العدد الكلي للبكتيريا القولونية في عينات الدجاج الطازج والدجمد كالتالى جلى جالى (4,07 ×

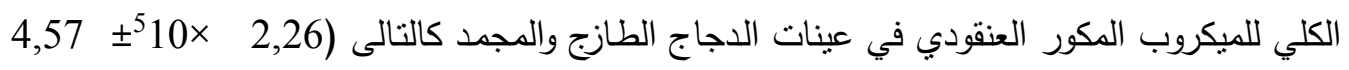
×10

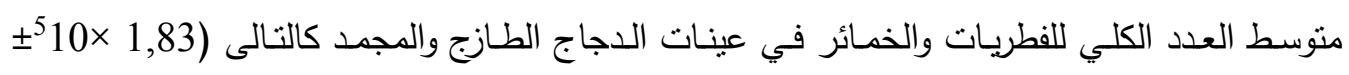

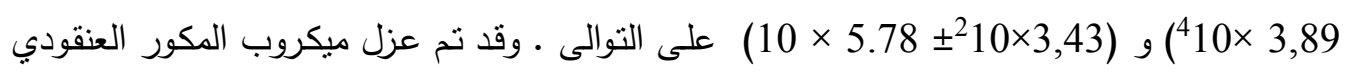
الذهبي من عينات الدجاج الطازج والمجمد بنسب 30\% و و 15 \% ع علي التوالي .كما تم عزل ميكروب

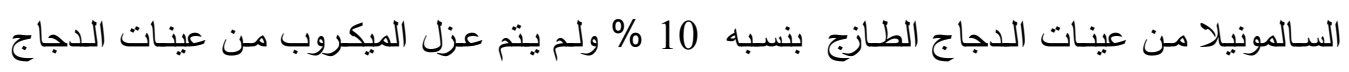

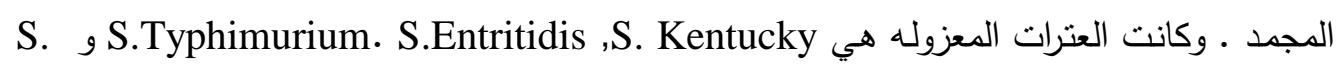
.ولم يتم عزل الميكروب من كلا من الدجاج الطازج والمجمد. 